\title{
Maria Renata Mayenowa. Dokumenty z lat studenckich w archiwum Uniwersytetu Stefana Batorego w Wilnie
}

\author{
Tomasz Chachulski
}




\section{Maria Renata Mayenowa. Dokumenty z lat studenckich w archiwum Uniwersytetu Stefana Batorego w Wilnie}

Tomasz Chachulski

TEKSTY DRUGIE 2017, NR 4, S. 318-335

DOI: $10.18318 /$ td.2017.4.19
NARODOWY PROGRAM ROZWOJU HUMANISTYKI

Praca powstała w ramach projektu badawczego pt. „Instytut Badań Literackich wżyciu naukowym, kulturalnym i społecznym PRL w latach 1949-1989. Postawy inteligencji wobec przemian społecznych i politycznych. Monografia środowiska intelektualnego". NPRH 0113/FNiTP/ $\mathrm{H}_{11 / 80 / 2011 .}$
$\mathbf{W}$ Litewskim Centralnym Archiwum Państwowym (Lietuvos centrinis valstybės archyvas) zachowały się teczki studentów, doktorantów i pracowników Uniwersytetu Stefana Batorego w Wilnie z lat 1919-1940. Na podstawie znajdujących się tam materiałów powstało już sporo różnych prac o charakterze przekrojowym lub biograficznym, ale z oczywistych przyczyn nigdy nie wykorzystano wszystkich dokumentów ${ }^{1}$. Korzystając z okazji, jaka towarzyszyła poszukiwaniom oryginału niewydanej wcześniej pracy doktorskiej Marii Renaty Mayenowej, przejrzałem to, co pozostało z lat jej studiów w archiwum dawnego USB ${ }^{2}$. Materiałów nie ma wiele - dwie stare, wyblakłe i podniszczone kartonowe teczki, do których badacze wileńskiej wszechnicy

1 Najważniejsza pracą jest tu: T. Dalecka Dzieje polonistyki wileńskiej 1919-1939, TNSV, Kraków 2003.

2 Kwerendę w sprawie rozprawy doktorskiej M.R. Mayenowej przeprowadziłem na prośbę prof. Marii Prussak, której bardzo dziękuję za inspirację do dalszych poszukiwań.

\section{Tomasz Chachulski}

(ur. 1958), dr hab., absolwent filologii polskiej KUL, prof. na Uniwersytecie Kardynała Stefana Wyszyńskiego i w Instytucie Badań Literackich PAN, historyk literatury; zajmuje się poezją polskiego oświecenia, wątkami oświeceniowymi w literaturze współczesnej, edytorstwem naukowym, dydaktyką literatury polskiej. Kontakt: tchachulski@op.pl 
rzadko dotąd zaglądali, kryją przede wszystkim urzędowe dokumenty dotyczące toku studiów, uzyskanego tytułu magistra i stopnia naukowego doktora. Pierwsza, opatrzona adnotacją „Gurewiczówna Rachela”, zawiera dokumentację studiów magisterskich, druga - „Kapłanowa Rachela"4 - związaną z uzyskaniem doktoratu. Pojedyncze dokumenty rozsiane są także w innych teczkach archiwalnych dawnego USB, szczególnie w zbiorach związanych z seminarium Manfreda Kridla ${ }^{5}$. Choć publikacje poświęcone Marii Renacie Mayenowej wyjaśniają lub prostują wiele okoliczności związanych z biografią uczonej, przytoczone niżej dokumenty pozwalają uzupełnić wiedzę o Jej studenckich latach ${ }^{6}$.

\section{$\% * *$}

Pod koniec lata 1927 roku młodziutka absolwentka białostockiego gimnazjum wypełnia kolejne dokumenty niezbędne do wstąpienia na Uniwersytet Stefana Batorego w Wilnie. Wpisuje odręcznie na blankiecie kwestionariusza trochę niewprawnym, ale zdecydowanym charakterem:

\section{Wydział historyko-filologiczny}

Kwestjonarjusz

1. Nazwisko

2. Imię

3. Imię ojca

4. Imię i nazwisko panieńskie matki
Gurewiczówna

Rachela

Benjamin-Lejb

Szejna Barasz

3 Fond 175, opis 5, IV Ca, 1127.

4 Fond 175, opis 5, IV B, 321.

5 Por. szczególnie: T. Bujnicki Maria Renata Mayenowa i seminarium Manfreda Kridla (komunikat), w: Obecność. Maria Renata Mayenowa (1908-1988), red. B. Chodźko, E. Feliksiak, M. Olesiewicz, Wydawnictwo UwB, Białystok 2006, s. 67-74.

6 Prócz wyżej wymienionych zob. także Okna pamięci. Maria Renata Mayenowa (1910-1988), wyb. tekstów do przedruku i red. B. Chodźko, E. Feliksiak, E. Konończuk, Wydawnictwo UwB, Białystok 2003. Prac poświęconych biografii i dokonaniom naukowym M.R. Mayenowej jest oczywiście znacznie więcej - prócz serii wypowiedzi o charakterze wspomnieniowym, jakie ukazały się po śmierci uczonej, warto wspomnieć najnowszy, osobno wydany szkic: T. Dobrzyńska Maria Renata Mayenowa i jej Pracownia: w 25. rocznicę śmierci, Wydawnictwo IBL PAN, Warszawa 2013.

7 W cytatach zapisanych odręcznie przez Mayenową pozostawiono oryginalną pisownię. 
5. Rok, miesiąc i dzień urodzenia,

6. Miejsce urodzenia

7. Narodowość

8. Wyznanie

9. Język macierzysty r. 19081 grudzień

Biatystok

Żydowska

Mojżeszowe

polski

10. Gdzie i jaką szkołę średnią ukończył Ukończytam szkołę średnią typu humanistycznego w Biatymstoku

11. Jakie ma świadectwa $\mathrm{z}$ poprzednich studiów

12. Adres obecny

Biatystok, ul. Sobieskiego $N^{\circ} 12$

Data $19^{30}{ }_{\text {VIII }} 27 r$. podpis własnoręczny

R. Gurewiczówna

Przy kwestionariuszu zachowało się podpisane na odwrocie zdjęcie wykonane przez „Zakład fotograficzny J. Rehoel, Białystok, Sienkiewicza $19^{\prime 8}$ w formacie przewidzianym dla dokumentów składanych w USB $(45 \times 63 \mathrm{~mm})^{9}$ i odręcznie zapisana połówka kartki formatu odpowiadającego mniej więcej dzisiejszemu B5 w tzw. jedną linię. Na takich właśnie dużych kartkach będzie pisała potem kolejne podania, prace ćwiczeniowe itp.:

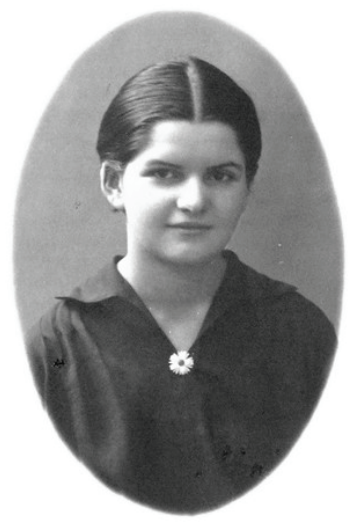

Życiorys.

Urodziłam się 1-go grudnia 1908 r. Wr. 1914 wskutek wybuchu wojny wyjechatam do Rosji. Tu zamieszkałam stale Charków, gdzie w r. 1917 wstapiłam do gimnazjum. Zajęcia moje zostały przerwane wybuchem rewolucji. Wr. 1922 powróciłam do Biategostoku, gdzie w r. 1923 wstapiłam do 4 klasy gimnazjum D. Druskina, które-to gimnazjum ukończyłam w r. 1927.

R. Gurewiczówna

8 W znanym mi wykazie zakładów fotograficznych działających w okresie międzywojennym w Białymstoku taka firma nie figuruje - w bliskim sąsiedztwie, pod numerem 12, działał zakład, którego właścicielem był Izrael Rendel i gdzie Rachela Górewiczówna robiła inne zdjęcia. Por.: http://bialystok.kolekcjonerski.com.pl/fotografia-w-bialymstoku2/zaklady-fotograficzne/ (12.02.2017).

9 Por. Informacja o wpisach i warunkach studiów w Uniwersytecie Stefana Batorego w Wilnie (Fond 175, opis 5, IV B, 249). 
i podanie

$19^{30} /{ }_{\text {VIII }} 27 r$.

Do W.P.Dziekana

wydziału humanistycznego

USB w Wilnie

Od Racheli Gurewiczówny

zamieszkałej w Biatymstoku

przyul. Sobieskiego No 12

Niniejszem proszę W.P.Dziekana wydziału humanistycznego o zaliczenie mnie w poczet stuchaczek zwyczajnych na rok akademicki 1927/8. Przytem załaczam:

1) Świadectwo dojrzałości

2) Metrykęurodzenia

3) Kwestjonarjusz

4) Życiorys

5) 3 fotografie

z poważaniem

R. Gurewiczówna

Wspomniane gimnazjum zostało założone przez Dawida Druskina w 1911 roku, przed wojną było uważane za jedną z najlepszych szkół prywatnych w mieście, prowadziło nauczanie w języku polskim. Jego absolwentami byli m.in. gwiazda polskiego kina - Nora Ney (Sonia Nejman) i Kalman Kaplansky - po wyjeździe do Kanady znany jako polityk i działacz ruchów na rzecz praw człowieka.

16 września 1927 roku zostaje przyjęta na Wydział Humanistyczny. Roczniki studentów USB tego wydziału stanowiły w tym czasie barwną mieszaninę narodowościową i wyznaniową. Niemal wszyscy kandydaci wpisują polską "przynależność państwową”, ale już przy narodowości zróżnicowanie jest znaczne: przeważa polska, ale znacząca liczba studentów polonistyki (a także wszystkich pozostałych kierunków) to Żydzi, wpisujący wyznanie "mojżeszowe” bądź „izraelickie”, a jako język „macierzysty”, zmieniony w następnych latach na formularzach na „ojczysty” - polski, ,jidysz”, „hebrajski”, „żydowski”, rosyjski. Są też nieliczni Białorusini (wyznanie prawosławne język polski bądź rosyjski), a wśród Polaków prócz dominującego wyznania rzymsko-katolickiego pojawiają się też ewangelicy i prawosławni. Na innych 
kierunkach Wydziału Humanistycznego (filologia klasyczna, filozofia, historia, germanistyka, pedagogika, psychologia) studiują także Rosjanie (filologia polska, słowiańska - prawosławni, język rosyjski), Niemcy (filozofia, germanistyka - język domowy niemiecki, katolicy lub wyznania reformowanego), Litwini (historia). Nierzadko jako miejsce urodzenia pojawiają się miejscowości położone w głębi Rosji (pod koniec lat 30. niektórzy studenci piszą już „w ZSRR”) lub na dzisiejszej Ukrainie - to Polacy, Żydzi, Rosjanie. Oczywiście - podanemu wyżej wykazowi daleko do kompletności, uwzględnia jedynie niecałą setkę przejrzanych kart rekrutacyjnych z kilku roczników z lat 30.

Górewiczówna studiuje, z czasem składa kolejne egzaminy - poświadczenia dotyczą takich przedmiotów jak: literatura powszechna, gramatyka opisowa języka polskiego, współczesna gramatyka języka polskiego i gramatyka starocerkiewnosłowiańska (z językoznawstwem ma wieczne kłopoty - będzie to najsłabsza strona jej studiowania), historia Polski, historia literatury polskiej, historia filozofii. Dodatkowo uczęszcza do Jana Safarewicza na kurs elementarny języka greckiego, który 17 marca 1932 roku zdaje na ocenę dobrą.

Choruje. 7 stycznia 1930 roku prosi o wycofanie dokumentów z komisji egzaminacyjnej, przedstawiając stosowne zaświadczenie. Białostocki lekarz okulista A. Szapiro diagnozuje ostre zapalenie spojówek, które ciągnie się przez niemal cały grudzień 1929 roku. Studia przerywa dwukrotnie na skutek trudności finansowych. 7 stycznia 1931 roku składa podanie o ponowne przyjęcie na Wydział Humanistyczny, powodem przerwania studiów była „niemożność uiszczenia opłat uniwersyteckich”. Do podania dołącza świadectwo maturalne. Zostaje przyjęta. Później na dole strony wielkimi literami, ołówkiem, na ukos dopisuje: Świadectwo dojrzałości zabrałam. R. Gurewicz-Kapłanowa ${ }^{10}$. Ale wówczas nie jest jeszcze mężatką.

14 grudnia 1931 roku składa znowu podanie, mieszka wówczas przy ul. Zawalnej (chyba 66/10 - cyfry są bardzo nieczytelne):

Z powodu absolutnej niemożności opłacenia w oznaczonym terminie opłat egzaminacyjnych, uprzejmie proszę o odroczenie mi tychże.

\section{Z poważaniem \\ R. Gurewiczówna}

10 Fotokopia tego świadectwa została opublikowana w: Obecność. Maria Renata Mayenowa (1908-1988), s. 384-385. 
Zataczniki:

1) Świadectwo niezamożności

2) Świadectwa $z$ dotychczas złożonych prac i egzaminów znajdują się w dziekanacie Wydziału Humanistycznego

*⿻*

wypisane na maszynie zaświadczenie brzmi następująco:

Magistratm. Białegostoku,

Wydz. II Administracyjny.

Dnia 20 X1931 r.Dz.L.42535 [...]

\section{ZAŚWIADCZENIE}

Magistrat m. Białegostoku zaświadcza, iż p. Gurewicz Benjamin-Lejb, syn Icka i Marjaszy, lat 53, zam. w Biatymstoku przy ul. Sobieskiego $N^{\circ} 12$, nigdzie nie pracuje, majątku żadnego nie posiada, jest człowiekiem niezamożnym i wraz z żona Szejna oraz córką Rachela, lat 23 /studentka/, utrzymuje się z pomocy swego brata D-ra Mojżesza Gurewicza.

Zaświadczenie wydaje się dla przedłożenia Władzom Uniwersyteckim w Wilnie.

Prezydent miasta:

podpis nieczytelny

okragła pieczęć

ręczny dopisek ołówkiem:

do 15 /III 32 odroczone

15/XII 31 podpis nieczytelny

Wnioski o odroczenie płatności, połączenie egzaminów (za każdy egzamin trzeba było osobno płacić, połączenie pozwalało zredukować opłatę o 50\%, jeśli student był w stanie przygotować tak znaczny materiał na raz) lub (bardzo rzadko) rezygnację z płacenia składało wielu studentów USB. Co prawda większość składała świadectwo n i e z a mo ż n o śc i lub „ubóstwa”, ale mniejsza o formy. W niektórych urzędach były nawet specjalne formularze, drukowane w większej liczbie wedle różnych wzorów na tę okoliczność. Po I wojnie światowej bardzo wielu ludzi mieszkających na kresach znalazło się w trudnej sytuacji materialnej - wielu kupców i przedsiębiorców straciło swoje majątki podczas wojny i rewolucji, mieszkańcom wsi brakowało tzw. inwentarza, pozwalającego uprawiać nawet niewielkie połacie posiadanej ziemi, rodzice studentów trudnili się handlem, utrzymywali się 
z „okolicznościowych zarobków”, zajęć dorywczych, emerytury, mieli kłopoty z utrzymaniem rodziny z nauczycielskich pensji, wdowy po prawosławnych duchownych czy małomiasteczkowych żydowskich lekarzach wpadały w skrajną biedę, młodzi próbowali udzielać korepetycji, jest nawet podanie „wdowy po psalmiście" spod Kowla i Rosjanina-sieroty - w tej sytuacji uzyskanie wykształcenia stawało się jedyną nadzieją na polepszenie bytu. Władze samorządowe miały na to dobitną formułę - „stan materialny bardzo biedny”, a dzieci bez majątku określano jako „niezaopatrzone”. Wnioski składali obywatele Rzeczypospolitej - Polacy, Żydzi, Białorusini, Rosjanie..., zaświadczenia wystawiali urzędnicy, ale też wileńskie stowarzyszenia studenckie (m.in. Stowarzyszenie Wzajemnej Pomocy Studentów Żydów). Zresztą wśród studentów Wydziału Humanistycznego USB prócz mieszkańców Wileńszczyzny znajdowali się także przyjezdni z Polski południowej, centralnej, północnej - Kalisza, Łodzi, Grudziądza, Rzeszowszczyzny, Kielecczyzny, Lubelszczyzny, okolic Sejn i z całego pasa wschodnich kresów od granicy z Litwą Kowieńską na północy (a nawet z Łotwy) aż po Polesie na południu włącznie; studiowali świeccy - wolni i żonaci czy zamężne - klerycy i księża.

Górewiczówna zdaje egzaminy - najgorzej jest z „gramatyką opisową współczesnej polszczyzny", przedmiotem wykładanym na pierwszym roku studiów - ocenę dostateczną otrzymuje dopiero przy trzecim podejściu, po trzech niemal latach - 8 stycznia 1932 roku. Zakres egzaminów językoznawczych był prosty: „pytania ze wszystkich działów gramatyki opisowej” - językoznawcy na USB nie zadawali sobie trudu wyszczególniania pytań; egzaminują profesorowie: Jan Otrębski (wcześniej docent Uniwersytetu Jagiellońskiego, profesor gramatyki porównawczej języków indoeuropejskich, a od połowy lat 30. także wykładowca języka litewskiego), Erwin Koschmieder (Katedra Filologii Słowiańskiej), Olgierd Chomiński. Potem przechodzi sprawdzian z dialektologii - tu pochodzący z Dolnego Śląska, pracujący wcześniej we Wrocławiu prof. Koschmieder jest dokładniejszy: pyta m.in. o formy językowe Kazań Świętokrzyskich, przegłos, liczebniki "dwa" i „trzy”, imperfekt i aoryst, funkcje narzędnika, dialekt wielkopolski itp. Zdaje też tzw. SCS, odpowiadając na pytania $\mathrm{z}$ historii i bibliografii starocerkiewnosłowiańskiej oraz z analizy tekstu (prof. Koschmieder). 2 października 1929 roku u Stanisława Pigonia zdaje pisemny egzamin z literatury polskiej, pisze o poezji powstania listopadowego. To tylko jej temat - każdy ze studentów na egzamin dostaje swoje, odrębne zagadnienie, specjalnie przygotowane przez Pigonia. Zirytowany egzaminator pisze w bardzo 


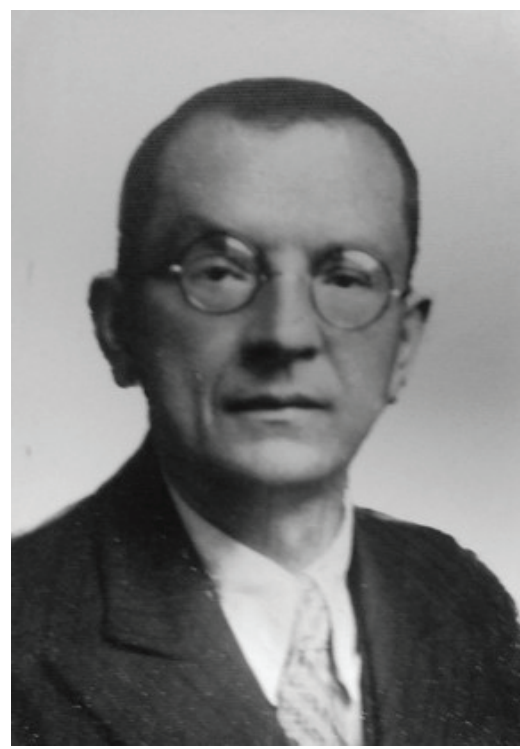

JAN OTRĘBSKI

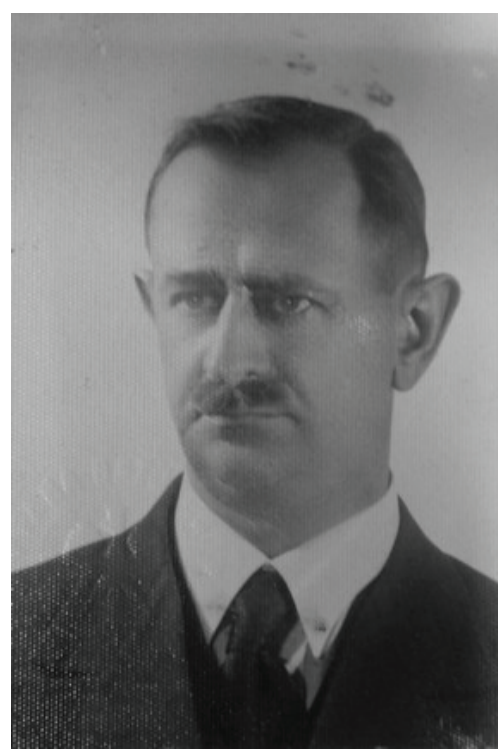

ERWIN KOSCHMIEDER

krótkiej recenzji: „Pobieżnie. Błąd ortograficzny! Dostatecznie”. W trzy dni później zdaje część ustną. Egzamin jest długi. Pigoń pyta ją o stan badań nad Bogurodzica, stopień oryginalności Dworzanina Górnickiego, literaturę mieszczańską XVII wieku, pamiętnikarstwo polskie XVII wieku, Franciszka Karpińskiego jako preromantyka, „,szekspiryzm” Słowackiego, historiozofię Krasińskiego, lirykę filozoficzną Asnyka i na koniec żąda, aby dokonała „przeglądu zwrotek używanych w poezji polskiej”. Całość ocenia na dostatecznie.

10 stycznia 1932 roku znany historyk Stanisław Kościałkowski egzaminuje z „historii politycznej, ustrojowej i kulturalnej Polski”. Zakres zagadnień jest również szeroki i szczegółowy: Acta Tomiciana i Volumina legum, najazdy tatarskie i ich znaczenie, sprawa koronacji Przemysła II, sekularyzacja zakonu kawalerów mieczowych, walki z Iwanem Groźnym o Inflanty, skład sejmu polskiego, uniwersał połaniecki, granice Księstwa Warszawskiego, Traugutt i jego rola - to przykładowe zagadnienia, przed którymi staje Górewiczówna, ponieważ nie wszystko daje się odczytać - Stanisław Kościałkowski wypełniał protokół niewyraźnie. Górewiczówna otrzymuje ocenę dostateczną.

Znacznie lepiej szły jej egzaminy z historii literatury. U Kolbuszewskiego i Glixellego zdaje historię porównawczą literatur nowożytnych. Mówi o Don 
Kichocie, liryce francuskiej XIX wieku i Szekspirze w Polsce. 23 czerwca 1931 roku dostaje ocenę dobrą. Stefan Glixelli, który ją pytał, to lwowianin z pochodzenia (urodzony w Stryju), wybitny romanista, przez pewien czas dziekan wydziału, człowiek nauki o wielkim autorytecie, znany m.in. z interwencji w sprawie słynnej likwidacji 52 katedr uniwersyteckich w 1933 roku, przeprowadzonej na mocy ustawy. Zmarł 28 listopada 1938 roku.

Wreszcie 10 i 11 października 1932 roku zdaje u Kolbuszewskiego Historie literatury polskiej ze szczególnym uwzględnieniem „Młodej Polski”, za całość otrzymuje wynik „bardzo dobry”. Egzamin znowu jest dwuczęściowy: pisemny („pod nadzorem”) na temat: Teorie literackie epoki Młodej Polski. Geneza i główni przedstawiciele. Pisze o przełomie XIX i XX wieku, ale sięga wstecz po początki literatury, wskazuje na relacje z innymi literaturami europejskimi (szczególnie Zachodu), wyprowadza z późnego romantyzmu szereg młodopolskich zjawisk literackich. Kolbuszewski jest bardzo zadowolony - zapisuje w recenzji: „wykazuje ogromne oczytanie i b. dobrą znajomość epoki”. Potem odpowiada jeszcze ustnie na szereg pytań, takich jak: najważniejsze opracowania literatury „Młodej Polski”, źródła zagraniczne tej literatury, zasadnicze zagadnienia poruszane przez pisarzy epoki, rola i znaczenie pierwiastka erotycznego w literaturze XVIII i XIX wieku, literatura po wielkiej wojnie, na koniec - stosunek literatury najnowszej do literatury rosyjskiej.

24 czerwca 1932 roku składa podanie o „przyjęcie i ocenienie załączonej przy niniejszem pracy magisterskiej pt. Wptyw Stowackiego na późniejsza poezję polska do r. 1930", napisaną pod kierunkiem prof. dra Kazimierza Kolbuszewskiego. W toku oceny tytuł zostaje zmodyfikowany na Wptyw Stowackiego na poezję polską do r. 1930. 28 czerwca 1932 roku Kolbuszewski przedstawia niewielką recenzję i ocenia pracę jako dobrą. Z datą 11 października 1932 roku na podstawie uchwały Rady Wydziału Humanistycznego USB wystawiono pani Racheli Gurewicz dyplom magistra filozofii w zakresie filologii polskiej. Z przedmiotów z zakresu wiedzy o języku ma wyłącznie oceny dostateczne; filozofia, historia porównawcza literatur nowożytnych - dobrze, historia literatury polskiej ze szczególnym uwzględnieniem Młodej Polski - bardzo dobrze.

Przez dwa lata nie pojawia się w dokumentacji Wydziału. 6 października 1934 roku jest znowu - zdaje ustny egzamin z psychologii ogólnej na stopień magistra filozofii w zakresie pedagogiki, jest to jej najwyraźniej potrzebne do podjęcia pracy w szkole. Egzaminuje prof. dr Mieczysław Dybowski - pyta ją o „rodzaje ruchów i czynności, podział barw, barwy neutralne, budowę i rodzaje spostrzeżeń, kojarzenie faktów psychicznych, badanie 
pola widzenia (perimetr), sprawdziany inteligencji, typy konstytucjonalne [Ernsta] Kretschmera i typy [Gerarda] Heymansa". Otrzymuje ocenę dostateczną.

W rok później, 12 października 1935 roku Rachela Kapłanowa z Gurewiczów na podstawie wcześniejszego magisterium, po odbyciu „przepisanej praktyki nauczycielskiej" oraz zdaniu na ocenę dobrą państwowego egzaminu „na nauczycielkę szkół średnich”, decyzją Komisji Egzaminów Państwowych w Wilnie na Nauczycieli Szkół Średnich otrzymuje Dyplom Nauczyciela Szkót Średnich uprawniający do "nauczania języka polskiego jako przedmiotu głównego w szkołach średnich ogólnokształcących i seminariach nauczycielskich państwowych i prywatnych w języku wykładowym polskim." Pracę podejmuje w Państwowym Gimnazjum Żydowskim.

15 października 1935 roku prosi o ponowne zaliczenie „w poczet słuchaczy zwyczajnych" Wydziału Humanistycznego. Mieszka w tym czasie przy ul. Kwiatowej 7/13. Karta przebiegu studiów poświadcza zdane egzaminy „W zakresie pedagogiki i nauk filozoficznych", wspomniany wyżej egzamin z psychologii ogólnej, a potem kolejne...

Najpierw ustny sprawdzian z historii filozofii starożytnej i średniowiecznej, egzaminuje prof. Bogumił Jasinowski (1 października 1936 roku). Jasinowski pyta ją m.in. o eleatów i Heraklita, tzw. paradoksy Zenona z Elei, działalność filozoficzno-naukową Arystotelesa, epikurejczyków, ale także o koleje zewnętrzne szkoły neoplatońskiej, św. Augustyna, filozofię Erigueny, św. Anzelma i jego „argument ontologiczny”, filozofię arabską i żydowską w wiekach średnich. Otrzymuje ocenę dobrą. Potem, również ustny, 8 stycznia 1937 roku, z „logiki i metodologii ogólnej z zasadniczemi pojęciami logiki matematycznej. Główne zagadnienia teorii poznania na stopień magistra filozofii w zakresie nauk filozoficznych", egzaminatorem jest prof. Tadeusz Czeżowski, również ocena dobra. Brak jednak jakichkolwiek dokumentów wskazujących na to, że studiowała dalej filozofię, choć prof. Czeżowski - filozof, logik i etyk - skupiał wokół siebie wielu młodych ludzi, odegrał też niezwykłą rolę w późniejszych latach Mayenowej, szczególnie w czasie wojny ${ }^{11}$. Rachela Kapłanowa musiała zachodzić do siedziby Czeżowskiego i jego uczniów.

Lokal seminaryjny, złożony z dwóch niewielkich pokoi o pięknych sklepieniach oraz większej sali, mieścił się na drugim piętrze domu stojącego

11 E. Rogalewska Białystok na szlakach życia Marii Renaty Mayenowej, w: Obecność. Maria Renata Mayenowa (1908-1988), s. 52. 
na obszernym dziedzińcu za Biblioteką Uniwersytecką, nazwanym dziedzińcem Sarbiewskiego. Lokal ten miał własną klatkę schodową, prowadzącą do jeszcze jednego pokoiku na poddaszu, znakomicie nadającego się na pracownię naukową dla kogoś szukającego ciszy i spokoju. Z czasem lokal seminaryjny został powiększony o jeszcze jedną obszerną salę na tej samej klatce schodowej. Mniejsza z dwóch sal została urządzona jako czytelnia studencka z podręczną biblioteką i czasopismami, w przylegających do niej pokojach mieścił się gabinet profesorski i pracownia asystenta. Dodatkowa duża sala została urządzona jako sala wykładowa. ${ }^{12}$

Immatrykulowana 19 stycznia 1928 roku.

L. Alb. 4755 .

Odbyła studja na Wydz. Hum. U.S.B.:

w r. 1927/28 - 3 trym, 1928/29 - 3 trym.

1929/30 - 3 trym. 1930/31 - 2 trym. i

$1931 / 32-1$ trym.

9 marca 1939 roku składa podanie o uznanie rozprawy „Wesele” Wyspiańskiego (problemy kompozycji) za rozprawę doktorską i dopuszczenie do egzaminu doktorskiego. Jako przedmiot poboczny wybrała „metodologię humanistyczną". Do podania dodaje oświadczenie o samodzielności rozprawy przygotowanej pod kierunkiem Manfreda Kridla, świadectwo dojrzałości, dyplom magisterski itp. Mieszka wówczas przy ul. Bouffałowej 21 m. 6 (obok Góry Bouffałowej).Wspomnienia o tym mieszkaniu - przestronnym, pięknym i doskonale wyposażonym - będą kilkakrotnie przewijały się w opowieściach przyjaciół i znajomych. Kilka kamienic dalej, pod numerem 5, w znajdującym się tam domu studenckim mieszkał wcześniej Czesław Miłosz.

Znowu pisze krótką notkę o sobie:

\section{Życiorys}

Urodziłam się w Białymstoku 1/ XII 1908 r. Od r. 1914 do 1921 mieszkałam z rodziną w Charkowie. Po powrocie z Rosji do Białegostoku wstąpiłam tam do Gimnazjum humanistycznego D. Druskina. Gim-

12 T. Czeżowski Wspomnienia (zapiski do autobiografii), „Kwartalnik Historii Nauki i Techniki” 1977 R. 22, $\mathrm{nr} 3$, s. 427-440. 
nazjum to ukończyłam w r. 1927/1928. Bezpośrednio po ukończeniu Gimnazjum zapisałam się na Wydział Humanistyczny Uniw. S. B. Studiowałam filologię polską. Dyplom magistra filozofii w zakresie polonistyki uzyskałam w r. 1932.

Po uzyskaniu dyplomu pracowałam w szkole średniej w Wilnie w charakterze nauczycielki języka polskiego i uzyskałam dyplom nauczycielski. Pracę w szkole przerwałam w r. szk. 1936/1937 dla opracowania tematu przedłożonej rozprawy.

Pracę przepisaną starannie na maszynie, oprawioną w grubą, tekturową okładkę zabezpieczoną na grzbiecie i rogach płótnem (strony I-VI i 1-239) recenzuje promotor i jako drugi - Konrad Górski. Kridl notuje odręcznie swoim prostym, równym, eleganckim pismem:

Ocena pracy doktorskiej Racheli Kapłanowej p.t. „Wesele” Stanisława Wyspiańskiego. Problemy kompozycji.

Praca zajmuje się tylko jedną stroną Wesela, a mianowicie zagadnieniem Kompozycja. Zagadnienie to jest jednak bardzo szeroko ujęte, gdyż obejmuje: tzw. tekst poboczny, przestrzeń dramatyczną, czas dramatyczny, zdarzenia dramatyczne, kompozycję aktów i scen, następstwo scen i "ruch tematów”, świat Wesela, świat motywów fantastycznych i problem jedności dramatycznej. Tem samem autorka porusza cały szereg problemów istotnych i ważnych dla dzieła i pokazuje, jak zagadnienia kompozycyjne wchodzą w głąb poszczególnych elementów dzieła i jaką w nich rolę odgrywają. To jest jeden pozytywny wynik pracy, osłabiony nieco tem, że pominięto znaczenie kompozycyjne języka poetyckiego i wiersza (ale to są zagadnienia specjalne, których opracowanie wymagałoby osobnych studjów).

Z innych wyników pozytywnych wymienić należy opracowanie (a przynajmniej poruszenie) całego szeregu zagadnień, dotąd w pracach nad Wyspiańskim nie uwzględnianych, i częściowo nowe oświetlenie kwestyj takich jak: tekst poboczny, przestrzeń dramatyczna i czas dramatyczny, kompozycja aktów i scen, „akcja” dramatyczna i problem jedności dramatycznej. W szczególności ujęcie trzech ostatnich kwestyj zasługuje na podkreślenie. W kompozycji aktów i scen wydobyto szereg ciekawych zjawisk, określono różne typy scen, oświetlono ich arealizm i marjonetkowość (ta ostatnia dobrze związana z tendencjami dramatu „modernistycznego") - przy omawianiu „akcji” stwierdzono jej nikłość 
w Weselu i wyciągnięto z tego konsekwencje, dotyczące znaczenia tego elementu wogóle w dramacie (zgodnie z nowoczesnemi teorjami o dramacie); w związku z tem autorka przedstawiła w sposób przekonywający, że nie tzw. akcja i walka dramatyczna stanowi istotę Wesela i nadaje mu jedność dramatyczną, lecz elementy emocjonalno-nastrojowe (co ma znaczenie dla teorji dramatu w ogóle!).

I w innych rozdziałach znaleźć można sporo uwag trafnych i wnikliwych, np. traktowanie postaci z punktu widzenia kompozycyjnego, dalej o kompozycji „szopkowej”, o realizmie i arealizmie itp. (teoretyczna kwestia „realizmu” jest jednak pominięta).

Chwalebne unikanie przez autorkę „teoretyzowania” i opieranie się wyłącznie na konkretnym materjale pociąga za sobą pewne braki i luki tam, gdzie przydałoby się trochę więcej teorji. Tak jest np. z Arystotelesem i wogóle z stosunkiem teoryj dramatycznych do Wesela, z wspomnianym już realizmem, z niezbyt przemyślanym operowaniem pojęciami takiemi jak muzyczność, operowość, recitativo, duet, zaczerpniętemi z zupełnie odrębnej dziedziny itp. Język i styl pracy wymaga tu i ówdzie poprawek.

Ogółem wziąwszy, praca p. Kapłanowej wykazuje nietylko zupełne opanowanie metody naukowej i samodzielne posługiwanie się nią, ale przynosi sporo nowych rezultatów ogólnych i szczegółowych, dotyczących Wesela, jest jedną z pierwszych prób na szerszą skalę zakrojonej analizy literackiej pewnego problematu - wykazuje ponadto duże oczytanie i orjentację w epoce, dzięki czemu poszczególne elementy dzieła traktowane są na tle porównawczym, co przyczynia się do określenia ich rodowodu literackiego. $Z$ tych względów praca powyższa czyni w zupełności zadość wymaganiom stawianym tezom doktorskim.

Wynik ogólny: bardzo dobry

Wilno, 20.04. 39.

Manfred Kridl

Z opinią powyższą najzupełniej się zgadzam. Konrad Górski

Wilno, 2.V. 1939

4 maja członkowie „Rady Wydziałowej” głosują dopuszczenie kandydatki do egzaminu (w drodze „obiegowej” - w tym dniu nie ma posiedzenia; formuła per currendam wymagała potem przedstawienia sprawy na najbliższym 
posiedzeniu Rady Wydziału w formie komunikatu odnotowywanego w protokole - tak stanowił pkt. 33 Regulaminu Rady Wydziatowej Wydziatu Humanistycznego USB z 16 listopada 1933 roku). Protokół podpisuje 14 profesorów (Jasinowski i Koschmieder są na urlopie, Rajmund Gostkowski nie bierze udziału w głosowaniu). Każdy z nich ma prawo uczestniczyć w egzaminie, faktycznie stawia się tylko komisja. Protokół podpisują: Tadeusz Czeżowski, Ludwik Chmaj, Konrad Górski, Henryk Elzenberg, Janusz Iwaszkiewicz, Stanisław Kościałkowski, Manfred Kridl, Henryk Łowmiański, Ryszard Mienicki, Kazimierz Moszyński, Jan Oko, Jan

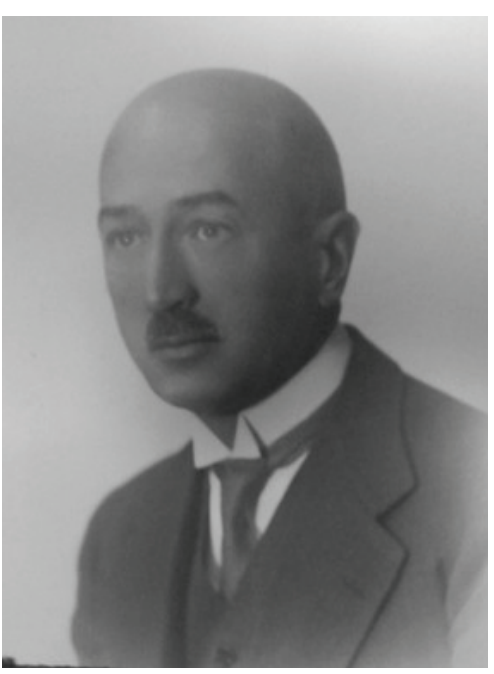

MANFRED KRIDL Otrębski, Stefan Srebrny i Stanisław Zajączkowski.

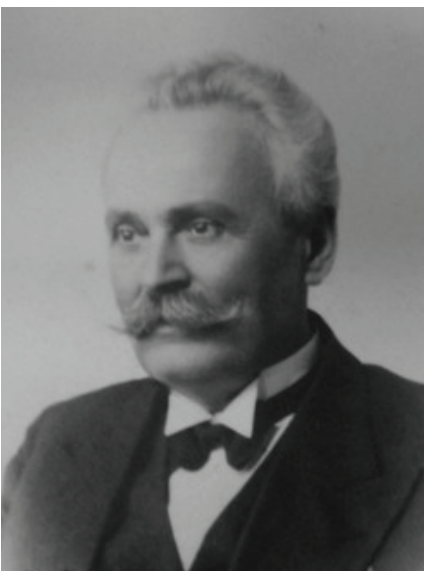

JAN OKO

5 maja 1939 roku o godzinie $9.00 \mathrm{w}$ gabinecie dziekana prof. dra Jana Oki (tak odmieniano wówczas jego nazwisko) odbył się "egzamin ścisły" mgr Racheli Kapłanowej. W komisji zasiedli: dziekan jako przewodniczący, referent główny (już w końcu lat 30. określano go często mianem promotora): prof. dr Manfred Kridl, koreferent (czyli recenzent) prof. dr Konrad Górski, egzaminator z przedmiotu pobocznego (dodatkowego): prof. dr Tadeusz Czeżowski (metodologia humanistyczna). Dokładnie tak, jak od strony formalnej regulowało to $\mathrm{Za}$ rządzenie Ministra Wyznań i Oświecenia Publicznego w sprawie uzyskania stopnia doktora z dnia 7 grudnia 1924 roku: „Egzamin ścisły [odpowiednik dzisiejszego egzaminu kierunkowego i egzaminów dodatkowych jednocześnie - T.Ch.] ma za zadanie sprawdzenie, czy kandydat posiada w należytej mierze przygotowanie teoretyczne, potrzebne do samodzielnego wykonania przedłożonej przezeń pracy oraz czy jest on należycie obeznany z literaturą opracowanego 
przezeń zagadnienia" (Art. 7). Z protokołu wynika, że Kapłanowa odpowiadała na 12 pytań z wiedzy o literaturze. Przytoczmy to świadectwo ówczesnej wiedzy teatrologicznej i literaturoznawczej. Pytanie rozpoczął Manfred Kridl $^{13}$ :

1. Problemat „akcji” i dramatyczności w historycznym rozwoju (w związku z tem ważniejsze teorie dramatu). Akcja w różnych typach dramatu i w Weselu.

2. Dramat a teatr.

3. Słowo poetyckie i dialog $\mathrm{w}$ dramacie.

4. Kwestia elementów „muzycznych” w Weselu.

5. Przestrzeń pozasceniczna w Weselu.

6. Rola dramatyczna widm.

Pytania Górskiego były - przynajmniej na pierwszy rzut oka - prostsze.

1. Czy wielowątkowość wprowadził dopiero dramat realistyczny?

2. Kwestia „żartobliwości” [...] aktu I-ego „Wesela”

3. Genealogia Stańczyka

4. Elementy satyryczny i tragiczny w „Weselu”

5. Teorie dramatu romantycznego w dobie romantycznej

6. Kwestia interpretacji Chochoła; możliwość jednoznacznej interpretacji a wartościowanie literackie tego pomysłu.

Tadeusz Czeżowski pytał m.in. o zadania nauk humanistycznych; opis w naukach humanistycznych; przedmiot badania nauk humanistycznych; ocenę w naukach humanistycznych itd. Na zakończenie dziekan wpisał z wyraźną satysfakcją, mocno podkreślając pojedynczą linią dwa ostatnie wyrazy: „Komisja uznaje, że kandydatka zdała egzamin ścisły z odznaczeniem”. W myśl ministerialnego rozporządzenia była to najwyższa możliwa ocena, jaką można było otrzymać podczas egzaminu doktorskiego. 22 maja 1939 roku o godzinie 6.15 (sic!), zapewne w „lokalu Komisji Egzaminacyjnej” (tam zbierano się zawsze w podobnych przypadkach), spotykają się członkowie Rady Wydziałowej na kolejnym posiedzeniu. Punkt 7 to głosowanie w sprawie doktoratu Racheli Kapłanowej. Uchwała zostaje podjęta jednomyślnie, choć tego dnia nie ma na posiedzeniu ani Kridla, ani Czeżowskiego.

13 W tym przypadku również zachowuję oryginalną ortografię. 
25 piątego maja 1939 roku zgodnie z dalszą procedurą dziekan prof. Oko pisze:

\author{
Senat Akademicki \\ Uniwersytetu Stefana Batorego \\ na ręce Jego Magnificencji \\ Ks. Rektora USB
}

Stosownie do art. 9 rozp. Min. W. R. i O. P. o doktoratach zawiadamiam, że Rada Wydziału Humanistycznego uchwata z dnia 22 maja 1939 r. przyznała mgr Racheli Kaptanowej stopień doktora nauk humanistycznych.

Termin promocji nie może być wyznaczony wobec tego, że praca doktorska kandydatki jeszcze nie ukazata sięw druku.

Dziekan

Wspomniane rozporządzenie stanowiło, że „Rektor wraz z Dziekanem oraz głównym referentem / promotorem/ dokonywa promocji kandydata na doktora, przyczem kandydat składa stosowne przyrzeczenie. Wręczenie kandydatowi dyplomu doktorskiego wraz z jego 5 odpisami może nastąpić dopiero po złożeniu przezeń w Rektoracie 100 drukowanych egzemplarzy pracy doktorskiej. Na karcie tytułowej egzemplarzy drukowanych winno być zaznaczone, że dana praca została przedstawiona w Szkole Akademickiej N. N. celem uzyskania stopnia doktora i przyjęta przez wymienionych imiennie referentów" (Art. 10).

Wileńskie doktoraty z zakresu nauk humanistycznych ukazywały się w serii „Rozprawy i Materiały Wydziału I Towarzystwa Przyjaciół Nauk w Wilnie” - w tym czasie tak np. została opublikowana rozprawa Zofii Abramowiczówny Études sur les hymnes homériques, Wilno 1937, tom IX, z. 1.

Zainteresowanie pracą jest spore - już w dniu egzaminu Kapłanowa zabiera jeden z egzemplarzy pracy z dziekanatu, 27 maja wypożyczany jest drugi egzemplarz Janinie Koziłowiczównie z seminarium polonistycznego Wydziału Humanistycznego, prośbę popiera Konrad Górski i Eugenia Krassowska, Kapłanowa zgadza się.

1 września rozpoczyna się II wojna światowa. 18 września 1939 roku „po porozumieniu się z autorką" Maria Rzeuska odbiera z uczelni świadectwo dojrzałości i dyplom magisterski. 19 września Armia Czerwona zajmuje Wilno. W drugiej połowie kolejnego miesiąca 1939 roku Związek Radziecki przekazuje Wilno - Republice Litewskiej. Dziekan i Rada Wydziałowa Wydziału 
Humanistycznego USB borykają się z nową sytuacją - Rada podejmuje stosowne uchwały pozwalające uruchomić kolejny rok akademicki, decyzje personalne, dziekan kieruje pisma do litewskiego kierownika Uniwersytetu, który zaraz po mianowaniu zaczyna wprowadzać nowe porządki, a od późnej jesieni - stopniowo przejmować majątek poszczególnych katedr. Doktoraty przyznane w poprzednich miesiącach nadal czekają na promocję, ale druk rozpraw nie jest już możliwy. W dokumentach Rady Wydziałowej sprawa doktoratu Racheli Kapłanowej nie pojawia się więcej. W księdze zatytułowanej Dyplomy doktorów filozofi i nauk humanistycznych ${ }^{14}$ w części „Doktoraty nowego typu (II stopień naukowy) od 1934 r.", w kolumnie „Data uchwały Rady Wydz. o nadaniu stopnia doktora" pod jedną datą - 9 grudnia 1939 roku - pod kolejnymi numerami wpisano ołówkiem trzy nazwiska: 11. Rachela Kapłanowa, 12. Marianna Rzeuska, 13. Maria Znamierowska-Prüfferowa. Ani zaproszenia na spotkanie, ani protokołu posiedzenia Rady z tego dnia nie ma jednak w stosownej teczce - są protokoły wcześniejsze i późniejsze, tego jednak nie ma, podobnie jak nie ma innego śladu, że takie posiedzenie się odbyło.

13 grudnia 1939 roku drukarnia Józefa Zawadzkiego, ulokowana przy ul. św. Anny 3, wydaje (najpewniej jednemu z pracowników Uniwersytetu) dyplom doktorski Racheli Kapłanowej. Druk kosztuje 18 litów. Tekst jest standardowy...

Dominam clarissimam Rachelam Kapłanowa civem polonam, oppido Białystok oriundam, postquam dissertatione, quae inscribitur „Wesele Stanisława Wyspiańskiego (Problemy kompozycji)" proposita eximiam in litteris Polonicis et in philosophia doctrinam probavit, doctorem litterarum creavimus et renuntiavimus in eiusque rei fidem hasce litteras Universitatis sigillo sanciendas curavimus. Vilnae, die IX decembris anno MCMXXXIX. Stanislaus Zajączkowski, h. t. prorector magnificus, Ioannes Oko, h. t. decanus, Manfredus Kridl, promotor. ${ }^{15}$

Tego dnia, tj. 13 grudnia 1939 roku - jak pisze Tadeusz Bujnicki - Rachela Kapłanowa odbywa promocję doktorską , ,jako jedna z ostatnich słuchaczek

Fond 175 , opis 5, IV B, $\mathrm{nr} 332$.

15 Kopia egzemplarza odebranego przez Rachelę Kapłanową została opublikowana w: Obecność. Maria Renata Mayenowa (1908-1988), s. 387. Kopia archiwalna pozostaje w archiwum dawnego USB. 
USB"16. Publikacja rozprawy doktorskiej, spełnienie ostatniego warunku pełnoprawnej promocji, nastąpiła jednak dopiero w roku 2013 - z inicjatywy prof. Marii Prussak ${ }^{17}$.

\section{Abstract}

\section{Tomasz Chachulski}

THE INSTITUTE OF LITERARY RESEARCH OF THE POLISH ACADEMY OF SCIENCES (WARSAW)

Maria Renata Mayenowa: Documents from Her Student Years at the Archive of Vilnius University

Chachulski presents documents kept at the Lithuanian Central State Archive (Lietuvos centrinis valstybès archyvas) and concerning the literary theorist Maria Renata Mayenowa (1910-1988), her student years, academic journey and the difficulties she faced while working towards the doctoral degree at Stefan Batory University in Vilius (1927-1939). Figures from the academic world who appear in the margins include members of the university's faculty, such as Tadeusz Czeżowski, Manfred Kridl, Erwin Koschmieder, Stefan Glixelli, Stanisław Pigoń, Konrad Górski and Kazimierz Kolbuszewski, as well as other staff members and students.

\section{Keywords}

Maria Renata Mayenowa, interwar Polish studies, Stefan Batory University, Vilnius, Lithuania

16 T. Bujnicki Maria Renata Mayenowa i seminarium Manfreda Kridla (komunikat), s. 72.

17 R. Kapłanowa [M.R. Mayenowa] "Wesele” Stanisława Wyspiańskiego. Problemy kompozycji, wstęp T. Dobrzyńska, oprac. tekstu i posł. M. Prussak, Wydawnictwo IBL PAN, Warszawa 2013. 